\title{
İRSETCONF
}

\section{THE INFLUENCE AND THE COMPARISON OF TURKISH PROCUREMENT SYSTEMS ON CONSTRUCTION PROJECT PERFORMANCE}

\author{
ILKNUR AKINER ${ }^{1}$,MUHAMMED ERNUR AKINER ${ }^{2}$ \\ ${ }^{1}$ Akdeniz University, Faculty of Architecture, Antalya, Turkey \\ ${ }^{2}$ Akdeniz University, Vocational School of Technical Sciences, Antalya, Turkey
}

\begin{abstract}
Procurement system is the invisible part of the construction project organizations and has an important effect to maximize the project performance. It rather concerns the management of the construction project process and participants to reach the common goals of completing the project under the budget, quality, and timeframes. There is a wide range of procurement systems that can be used to manage the construction of a project. Design-Build, Traditional and Turnkey procurement systems, which contain Lump Sum, Unit price and Cost plus a fee contract types and methods, are mostly used procurement systems in the Turkish construction industry. Each of these systems has its advantages and disadvantages which the owner must consider before the project begins. The evaluation of procurement systems and to select the right system is a complex decision problem and depends on many factors for the owner. Factors that the owner should consider are the complexity of the project, the relative importance of budget or schedule and the in-house expertise the owner has to manage the project. Within this study, a survey was conducted with some of the construction project owners in Turkey. The objective of this study is the empirical performance-based investigation of the procurement systems mostly used in the Turkish construction industry today. Another goal is to determine the influences of these procurement systems on project cost, time and quality factors in Turkish construction sector and to determine the extent of these systems that are covering the needs of project owner (client).
\end{abstract}

Keywords: Turkish construction industry; procurement system; project performance 


\section{IRSETCONF}

\section{Introduction}

Over the last three decades, the European Union (EU) has had a strong influence on the way public institutions promote market philosophies in their own policies. EU procurement directives, globalization, and harmonization of markets attract more attention to the procurement practices of public institutions. Procurement systems continue to foster the interest of practitioners and academics as standardization is difficult due to the nature of this task, which is different from its nature. The procurement concept in construction has been defined in many ways (McDermott, 1999) and various terms were used by various researchers and practitioners for the term procurement system. It includes terms related to procurement systems, project delivery methods, procurement methods, procurement routes, project approach and contractual arrangements (Oshungade and Kruger, 2015). Therefore, the term procurement system is used for this research. Discussions about the construction sector has shifted from a challenging technological system approach to soft systems based on explaining the performance differences. The concept of procurement system has become an important issue in the construction industry because construction involves a series of interconnected and sequential processes for the procurement of construction projects (McDermott, 1999; Shrestha et al., 2012). Martins and Taylor (1996) examined the concept of culture in the context of the procurement policies of the reconstruction and development program in South Africa. Their arguments were based on an anthropological methodology, where procurement and contract practices should be based on principles that conform to indigenous cultural values. Kumaraswamy (1994) discusses the availability of advanced countries procurement systems when applied to less developed countries and argues that a sustainable and synergistic procurement strategy should be developed in such cases. Newcombe (1994) argues that selection criteria for procurement systems are less important than the fact that procurement paths create power structures that significantly affect the final success of the project. However, it is generally accepted that selecting the most appropriate procurement system is critical for both customers and project participants (Love et al., 1998). In 1997, the CIB Commission challenged hypotheses attempting to establish the relationship between procurement and innovation and the following definition was adopted: Procurement is a strategy to satisfy client's development and/or operational needs with respect to the provision of constructed facilities for a discrete life-cycle (Davidson, 1998). The official objectives of the CIB Working Group W92-procurement systems imply that the procurement process is a social science and that it can contribute to understanding the disciplines of history, sociology, economics, psychology, law, and politics. Evidence suggests that the selection of an appropriate procurement strategy is an important part of overall project success, and this has been a driving force for the development of various procurement selection approaches (Rahmani et al., 2017). Although numerous studies have tried to search different aspects of procurement systems, such as the selection process, the effect of procurement choice on project performance; 


\section{IRSETCONF}

it is the absence of a study focused on modern, fully relationship-driven distribution systems, such as alliancing, early contractor involvement, integrated project delivery, and the historical adoption of relationship-based procurement. Moreover, there is a lack of information about efficiency concepts and evaluation of the resulting procurement systems when used for a construction project (Rahmani et al., 2017). Today, the existence of a wide range of procurement systems to project developers on the market has led to a variety of comparisons on how different procurement systems are performed at the end of the construction phase (Muriro and Wood, 2010). Since many variables affect project performance during the execution phase the objective of this paper is to critically analyze and to review the use of various construction procurement systems, both globally and specifically within the Turkish construction industry context through the existing literature. Thus, for the purpose of this study, this paper presents a comparative study on the procurement systems used in the Turkish construction industry both public and private sector based on quantitative data gathered from 770 construction project completed between the years 2007-2016.

\section{Procurement System of Building and Construction Project Works}

Construction projects are complex organizations and resources to achieve a common goal, i.e. a building, road, bridge or other human-designed structure. Procurement system is a management process involving the complex integration of technical, political, environmental, economic and project components carried out by many professionals to achieve the common goals of completing construction projects in budget and tight time frames (Plugge, 2007). The project management professionals have different lenses to display the procurement systems and the term is broadly defined and used to describe various assets, such as functions, organizations, resources, systems, processes, and strategies have become important to business success (Rahmani et al., 2017). Rowlinson (1999) explain that the procurement system is the acquisition of project resources for the realization of a construction project, and this may be directed to the process of bringing together the necessary resources. The procurement also refers to other features such as culture, management, economy, environment and political issues (Rowlinson, 1999). Fisk and Reynolds (2013) identify project procurement as the organization of people, relations with the contractor, communications, business systems, procedures, responsibility authority, and duties of all the participants of the project life cycle. Procurement is commonly known as the process of obtaining something, hence, according to Adenuga (2013) the procurement system is the method used to provide a project, however, in the writings by Oyegoke and Kiiras (2009) and Crumm (2012), project procurement is described as a procedure and organized processes or methods, which are used by project owners (clients) to acquire or obtain construction products. On their part, Sobin et al. (2010) and Leu and Lin (2008) described project procurement as the structure of an organization that is required to design and build 


\section{IRSETCONF}

construction projects for the project owner. According to Elzarka (2009), the project procurement of construction projects is wide in scope and it involves the collection and organization of various individuals, and companies to design, manage, and build construction products. Nevertheless, the procurement system is a process in which a design and construction component, such as the procurement method, the roles, and responsibilities of the parties involved, the sequence of activities, material costs, and labor, are combined to deliver a project (Shrestha et al., 2012). In order to undertake project procurement, project owners use procurement systems, which are an invisible part of the construction project and they have a significant impact on the project performance (Alhazmi and McCaffer, 2000). There are numerous procurement systems but they differ in regards to activities sequencing, the allocation of duties, procedure, process, and the approach on project delivery. Alhazmi and McCaffer (2000) stated that these differences resonate the differences that are visible on project performance. Gruneberg and Hughes (2004) claims that despite the widely adopted nomenclature, there is a wide range of strategies available since there are too many variables to each of the commonly adopted procurement strategies. Masterman (2002) classified procurement systems broadly into four main groups have emerged and are in use in the construction industry: (1) separated procurement systems (traditional systems); (2) integrated procurement systems (design and build); (3) management-oriented procurement systems (construction management); (4) discretionary/collaborative system (Partnering). Construction project procurement systems are mostly classified into two main groups; Traditional and Alternatives (Adenuga, 2013; Oshungade and Kruger, 2015). Due to the lack of traditional procurement systems, innovative procurement systems are often referred to as alternative procurement systems. These alternative procurement systems include the Design/Build (DB), the Construction Management (CM), and the Management Contracting Procurement (MCP) method (Shrestha et al. 2012). Procurement systems determine the type of contract relationships used in the construction project. What is important is that different procurement systems require different organizational and institutional arrangements as well as different procurement processes (Riley and Lewis, 2008).

\section{The traditional procurement system}

Doloi (2013) defined the traditional procurement system as a procurement method whereby the key phases of designing, biding, and building are clustered as separate tasks and therefore, different parties are invited to bid for the designing and construction tasks. Under this system, the project owner usually spells out the project objectives and scope before inviting bids. In the Constructing the Team report Sir Michael Latham concluded that the industry's traditional methods of procurement and contract management and its adversarial culture caused inefficiency and ineffectiveness (Latham, 1994). 


\section{IRSETCONF}

\section{The design-build procurement system}

With reference to the writings by Grau et al. (2012), it noted that the design-build (DB) is a procurement system that is commonly used in the construction industry. Arditi and Ongkasuwan (2009) and Migliaccio and Shrestha (2009) described it as a system of delivering a project whereby a single constructor also known as the design-build constructor designs the entire project as well as carry out the actual construction activity. The unique fact about this system is that the constructor bears all the responsibilities of the project.

\section{Construction Management procurement system}

Construction Management (CM) is similar to DB because it treats the project planning, design, and construction phases as integrated tasks. This procurement system combines the project team of the owner, designer, and contractor. The key difference between this system and DBB is that the construction manager is in a non-adversarial or consultant relationship with the owner, designer, and contractor, allowing the owner to participate in the design and construction process (Fisk and Reynolds, 2013). In addition, in terms of project management, meeting the basic project objectives (Time, budget and quality) is considered as the main criterion for a successful project (Chan and Kumaraswamy, 1997).

\section{Impact of the procurement systems on the project budget}

According to Shrestha and Mani (2013), project budget refers to the overall amounts consumed at the initiation of the project until its conclusion and the factors that can contribute to failure in keeping the project within the budget include underestimation of costs, high inflation, unfavorable exchange rate, and interest rate during the period of undertaking the project. Others include modification of the design during the construction phase and the inclusion of new items into the project. From, the perspective of the project owner or the client it is only the turnkey procurement system that can guarantee that there will be no increase in project budget (Arditi and Ongkasuwan, 2009; Chang, 2009). As for the design-build and traditional approach, the project owner can contribute to increase in price since he or she can request for modification on the design or the inclusion of new items on the construction product. Additionally, the fact that the project owner finances the construction project means that he or she might incur increased project cost due to external factors such as high inflation, which will increase the cost of materials (Lopez and Love, 2012). 


\section{IRSETCONF}

\section{Impact of the procurement systems on the project quality}

According to Haponava and Al-jibouri (2012), the quality of a construction project is the totality with which the features of a project satisfy the need for the project owner and even the purpose of the project. Factors that influence the quality of a project include the extent to which the project is supervised by the client, the experience of the consultants involved in the project, and the constructor's record of accomplishment (Elzarka, 2009). Under the turnkey procurement system, clients are forced to accept the constructors' quality of work and undertake any modification on their own. However, under the design-build and the traditional procurement systems, the project owners can influence the quality of the project by strict supervision of the construction work, and selection of experienced project consultants as well as constructors.

\section{Impact of the procurement systems on the project time}

Leu and Lin (2008) stated that project time infers to the adherence of the time schedule that was allocated for each phase of the project and overlap of time is detrimental as it can possibly increase the project cost. It is only under, the turnkey procurement system whereby the client does not have to consider the time issue since the constructor will invite purchase orders upon completion of the entire project or when the project is within the final stages. As for the design-build and the traditional system, they are prone to time delays because of force majeure clauses that might halt the construction process and even issues such as lack of funds, machine failures, or unavailability of certain skilled workers to undertake certain specified and unique tasks (Arditi and Ongkasuwan, 2009).

\section{Procurement Strategy in Turkish Construction Industry}

The evaluation and the choice of the most appropriate procurement system are critical and it is a complex decision problem to both the customer and the other project participants because it is an important factor that contributes to overall customer satisfaction and project success (Oshungade and Kruger, 2015). In the writings by Elzarka (2009), he stated that under project management, project performance simply refers to meeting and/ or surpassing the project owner's needs and expectations on the entire project or the degree of success of a particular project using a particular procurement system. According to Haponava and Al-jibouri (2012) and Boeckmann (2009), a successful project is one whereby the project has been completed and handed over to the project owner on or before the earlier agreed date, it has remained within the stipulated budget and within the original scope, and it meets the desired quality. Rowlinson (1999) discussed a systems view of procurement is important to recognize that elements such as contract strategy and the client are functional parts of the procurement system. However, the effectiveness of the client organization or the contract strategy is changed 


\section{IRSETCONF}

by other procurement system variables such as culture, sustainability, economic and political environment and more practical concepts such as partnering (Rowlinson, 1999). The Turkish construction industry is highly regarded in the global construction industry because of its prowess, which enabled it to be ranked as the 2nd largest in the world in 2009 by the Engineering News-Record. Thirty-one Turkish firms have made it onto international construction sector magazine Engineering News-Record's (ENR) Top 225 Global Contractors 2009 list, making Turkey second only to China in terms of its total number of firms on the list. The construction industry is among the leading industries in Turkey and most of the Turkish construction companies are featured in the top international list of constructors (Akiner and Akiner, 2009). Turkish construction industry has been accelerated in the last 30 years with economic growth aspects of scale and quantity. Turkish Construction and Architectural Services serve several benefits such as low-priced labor force and geographical position close to the Middle East and Russia. As a result, by using these advantages Turkish construction industry became competitive in the construction sector especially in the Middle East and Russia after the 1980's. After determining the primary strategy for a project, a number of particular factors such as project characteristics, client resources, budget issues, timing, ability to make changes and external factors should be taken into consideration when evaluating the most appropriate procurement strategy (Rowlinson, 1999). Mustapha et al. (1994) discussed how the liberation of the economy in Turkey, which was implemented through the promotion of design-build-own-operate-transfer procurement systems, ultimately resulted in increased activity by Turkish contractors in neighboring countries. In Turkey, provision and financing of large-scale projects have been predominantly undertaken by the Government. Turkish Government is encouraging the private sector participation in the development of construction, infrastructure facilities such as railways, airports, water supply facilities. The private sector has an important role to play in financing major projects in Turkey. Build-operate-transfer (BOT) Project concept was coined in 1984 by the Turkish PM Turgut Ozal within the framework of the privatization of Turkish's public sector projects and captured the world's attention especially of developing countries. (Tiong, 1990; Ozdoganm and Birgonul, 2000). The contractor, the clients (the owner of the land, building owner), sub-contractors and technical team are the principle stakeholders through a project life cycle in the Turkish construction industry. In this process, the contractor as a major participant is the broker for all design and construction works. The designer and engineering group are the technical representatives of both the client and the contractor. Frequently used and most popular, common types of project procurement systems are include traditional and design-build. Similarly, the most popular contract type is turnkey and under the turnkey contract type, the constructor performs the designing as well as the construction task and then invites prospective clients to make an offer on the construction product or simply acquire the completed project at its market 


\section{IRSETCONF}

price (Arditi and Ongkasuwan, 2009). Under this system, the clients have no influence on any of the project phases since they buy a completed construction product.

\section{Methodology}

The research presents literature focuses on the influence and the comparison of Turkish procurement systems on construction project performance. In regards to the procurement system, the study will limit itself to only discussing the design-build procurement system, the traditional procurement system, and the project management procurement system, which are commonly used in the Turkish construction industry. It is of the essence to note that these three procurement systems contain turnkey, lump sum, unit price, and cost plus a fee contract types and methods, and they present certain advantages as well as drawbacks to the project owner. The collected data were then grouped in frequency distribution tables to facilitate strict and effective interpretation, analysis. Out of 770 construction projects primary data based on a combination of mailed questionnaires and semi-structured interviews are collected in order to address the overall aims and objectives of the main research. The primary goal of this research, however, was to undertake a comparative analysis of different procurement methods used in successful construction projects in the Turkish construction industry completed between 20072016.

\section{Findings and Discussion of Results}

Totally, 770 number of construction projects completed in several cities where the Turkish construction industry developed most are focused on and are analyzed statistically both public and private sector. From the remaining total percentage of the construction projects $21,0 \%$ were tendered in the Public sector and $78,8 \%$ were tendered in the private sector. The construction projects and the procurement systems used to complete it may give clues about the structure of the construction industry. The number of the construction project is used as the base for the analysis of the procurement system, type of the contract, project types or building types, stakeholders, and how they change according to each other is discussed. The results of the project characteristics related to the procurement systems of completed construction projects are summarized and discussed in the figures and tables provided. Figure 1. indicates the percentage by weight of the procurement systems used in construction projects in the Turkish construction industry. Traditional procurement approach has the highest percentage usage among the other procurement systems employed for the construction projects. Each of these project procurement systems is unique in its management structures, organization, and the influence of the stakeholders have on the project. From the remaining 770 number of projects, $317(41,2 \%)$ were tendered using the Traditional procurement system, $220(28,6 \%)$ 


\section{IRSETCONF}

were tendered using the Design-Build procurement system, 104 (13,5\%) for the Project Management and $48(6,2 \%)$ for the Construction Management. The traditional approach is the most popular and frequently used system with the highest percentage at $41,2 \%$, on the contrary, collaborative and innovative procurement systems like partnering have the lowest percentage compared to the others.

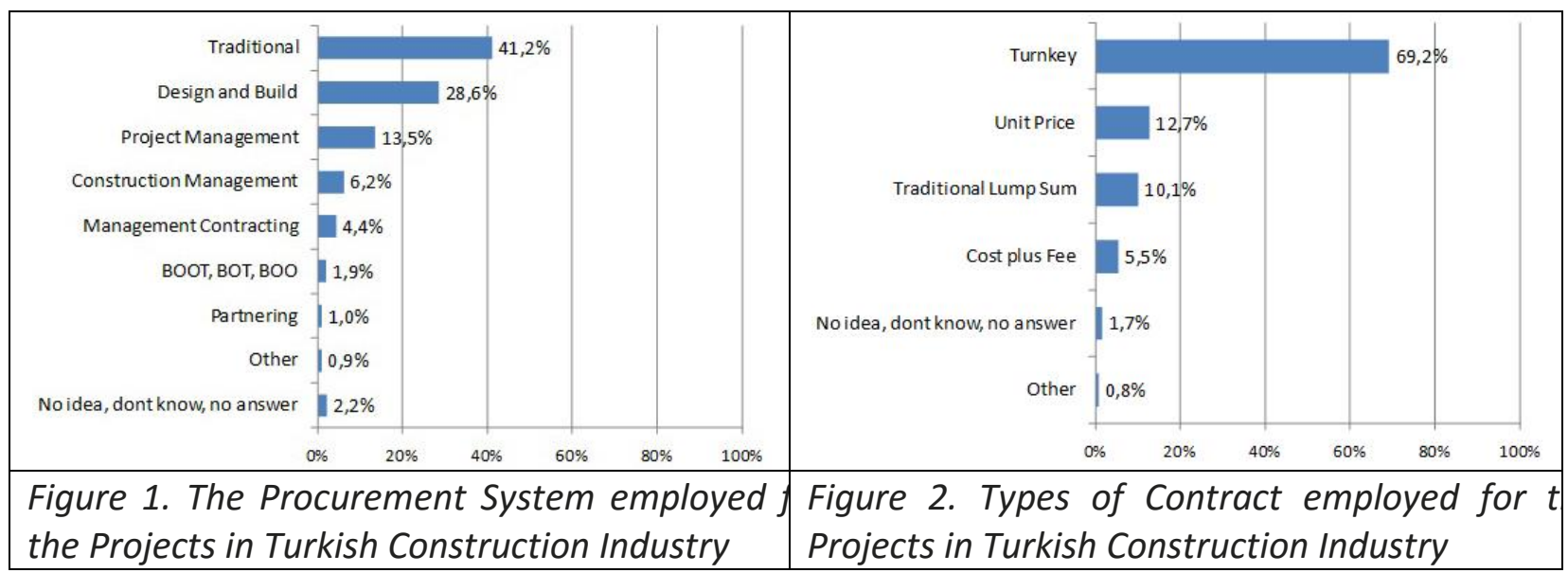

Figure 2. shows that $69,2 \%$ (533) of the projects are taken up by "turnkey" way of contracting. This contract type has a direct relationship with the project type production besides the procurement system. Most of the housing project types are provided by the private sector in the Turkish construction industry. Also, most of the contractors are generally organized a contract together with the clients in other words landowners under the rules of flat-for-lands. And, the contract details covering the turnkey depends on the agreement between the contractor and the landowner. Expected quality-budget and timing about the construction mostly depends on the project details guaranteed with the contract. Totally, $533(69,2 \%)$ number of Turnkey types of contracts employed for the projects in the Turkish construction industry, followed by $98(12,7 \%)$ Unit Price, 78 (10,1\%) Lump Sum and 42 (5,5\%) Cost plus Fee. Involvement of project participants (Public and Private Sector Client) in the different procurement systems and the different Types of Contract are clustered in construction projects. Projects are analyzed according to the procurement systems and compared to the project participants in the different project sector completed in public and private sector of the construction industry in Turkey. Table 1. presents the involvement of project participants in the different sector and indicates that the private sector is the highest user of Design and Build procurement system. On the contrary, turnkey contract types are respectively employed $52,5 \%$ in public sector which means lower than private sector which means turnkey is the most popular and frequently used contract type in private sector with the highest percentage at $73,6 \%$. (Table 2.). Similarly, from Table 3 . it can be seen 


\section{İRSETCONF}

that the projects used traditional procurements system preferred traditional Lump-Sum contract type with the highest percentage at $67,9 \%$.

Table 1. Public and Private Sector Client in the different procurement systems

\begin{tabular}{|l|l|l|}
\hline & Public & Private \\
\hline Traditional & $44,4 \%$ & $40,4 \%$ \\
\hline Project Management & $13,6 \%$ & $13,5 \%$ \\
\hline Management Contracting & $8,6 \%$ & $3,3 \%$ \\
\hline Design and Build & $19,1 \%$ & $31,0 \%$ \\
\hline BOOT, BOT, BOO &, $0 \%$ & $2,5 \%$ \\
\hline Construction Management & $9,9 \%$ & $5,3 \%$ \\
\hline Partnering & $1,9 \%$ &, $8 \%$ \\
\hline Other &, $0 \%$ & $1,2 \%$ \\
\hline No idea, don't know, no answe & $2,5 \%$ & $2,1 \%$ \\
\hline
\end{tabular}

Table 2. Public and Private Sector Client in the different Types of Contract

\begin{tabular}{|l|l|l|}
\hline & Public & Private \\
\hline Traditional Lump Sum & $11,7 \%$ & $9,7 \%$ \\
\hline Turnkey & $52,5 \%$ & $73,6 \%$ \\
\hline Cost plus Fee & $6,8 \%$ & $5,1 \%$ \\
\hline Unit Price & $25,3 \%$ & $9,4 \%$ \\
\hline Other & $1,9 \%$ &, $5 \%$ \\
\hline No idea, don't know, no answe & $1,9 \%$ & $1,6 \%$ \\
\hline
\end{tabular}

Table 3. The procurement systems and Types of Contract employed for the construction projects

\begin{tabular}{|c|c|c|c|c|c|c|}
\hline & 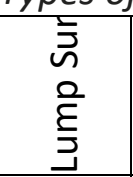 & 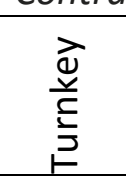 & 苍 & 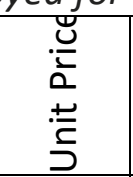 & 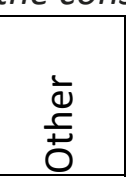 & 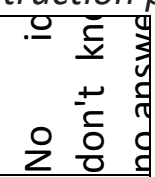 \\
\hline Traditional & $67,9 \%$ & $37,0 \%$ & $40,5 \%$ & $44,9 \%$ & $16,7 \%$ & $38,5 \%$ \\
\hline Project Management & $12,8 \%$ & $11,1 \%$ & $21,4 \%$ & $22,4 \%$ & $33,3 \%$ & $15,4 \%$ \\
\hline Management Contracting & $1,3 \%$ & $4,9 \%$ & $2,4 \%$ & $4,1 \%$ & $16,7 \%$ & 7,7\% \\
\hline Design and Build & $10,3 \%$ & $33,8 \%$ & $31,0 \%$ & $16,3 \%$ & $33,3 \%$ & $7,7 \%$ \\
\hline BOOT, BOT, BOO & $2,6 \%$ & $2,4 \%$ & ,0\% & ,0\% &, $0 \%$ & ,0\% \\
\hline
\end{tabular}




\section{IRSETCONF}

\begin{tabular}{|l|l|l|l|l|l|l|}
\hline Construction Management & $3,8 \%$ & $6,2 \%$ & $4,8 \%$ & $10,2 \%$ &, $0 \%$ &, $0 \%$ \\
\hline Partnering &, $0 \%$ & $1,5 \%$ &, $0 \%$ &, $0 \%$ &, $0 \%$ &, $0 \%$ \\
\hline Other & $1,3 \%$ & $1,1 \%$ &, $0 \%$ &, $0 \%$ &, $0 \%$ &, $0 \%$ \\
\hline No idea, don't know, &, $0 \%$ & $2,1 \%$ &, $0 \%$ & $2,0 \%$ &, $0 \%$ & $30,8 \%$ \\
\hline
\end{tabular}

The level of usage of the procurement system varies depending upon the type of project as it is seen in Figure 3. Traditional procurement approach is the most used procurement approach varies depending upon the type of project. Traditional procurement system is especially the main approach for non-housing buildings whereas "Traditional" and "Design and Build" approaches are almost equally used for housing. "Project Management" is used more for civil engineering projects. Traditional procurement approach is especially the main approach for non-housing buildings whereas "Traditional" and "Design and Build" approaches are almost equally used for housing. "Construction Management" is used only for civil engineering projects. Similarly, as shown in Figure 4., 33,8\% of the civil engineering projects are carried out with "unit price" contract. "Turnkey" way of contracting is used most for housing project types. The building, civil engineering, and housing are the top three project types used in the Turkish construction industry. Furthermore, "Turnkey" way of contracting is used mostly for housing. The civil engineering projects are carried out with "unit price" contract.

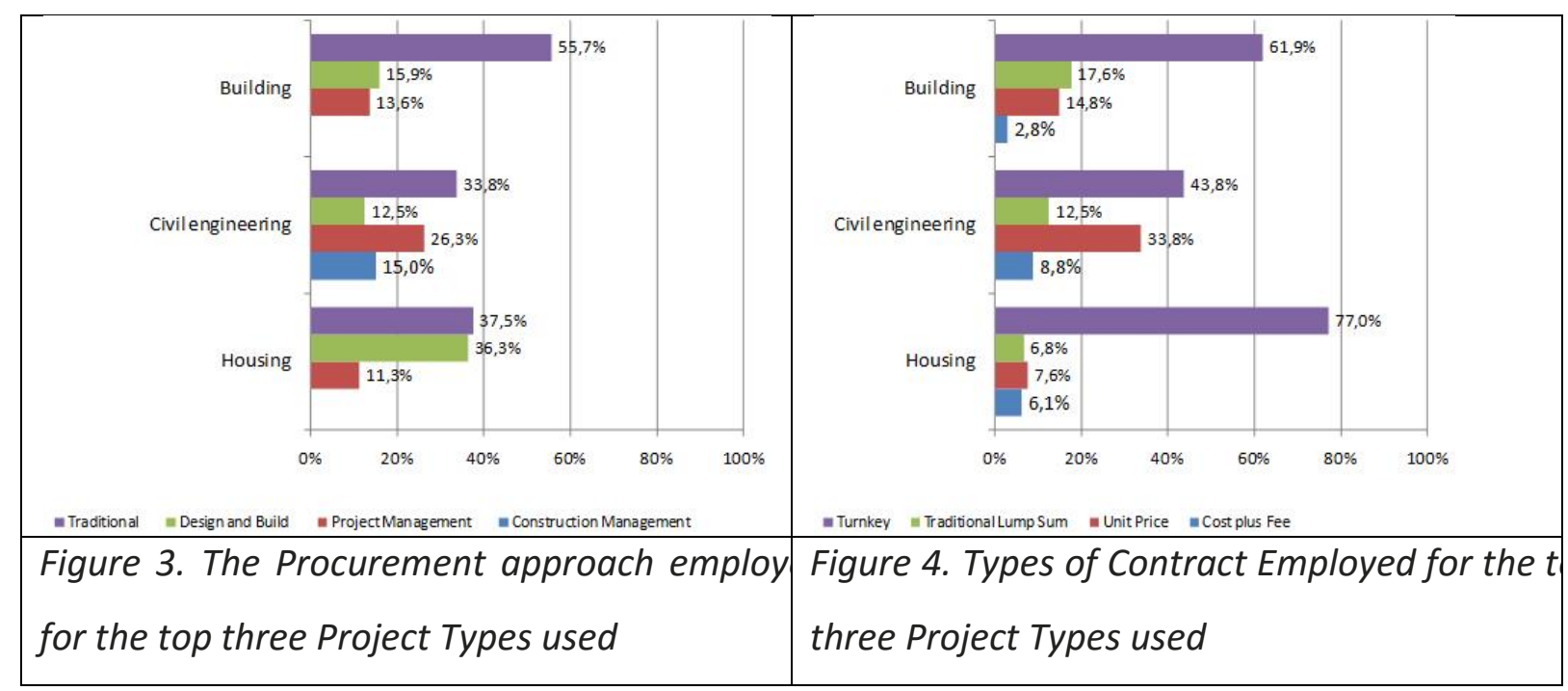




\section{IRSETCONF}

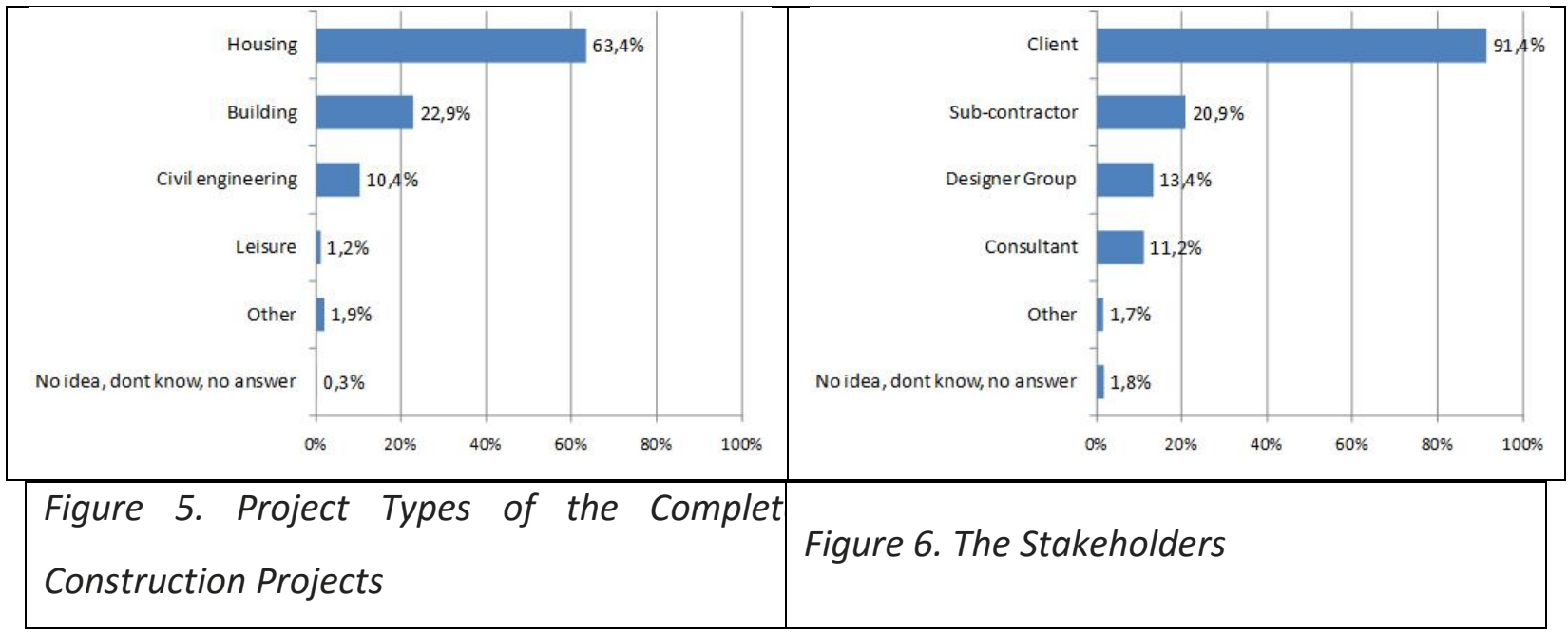

Figure 5. shows the percentage of the project types of the completed construction projects in the Turkish construction industry. From the figure, housing projects have the highest percentage at $63,4 \%$, followed by non-housing Building with $22,9 \%$. Housing construction is the most produced building type within the completed projects. Actually, the media is an important indicator of this statistical result with the advertisements of housing marketing regarding the producing housing. Project participants of the construction industry or the stakeholders have already formed a contract for a construction project with the contractor companies which means most influential actors among others are analyzed within the scope of the research. Figure 6. indicate that construction companies are mostly forming a contract with the clients $(91,4 \%)$ for these projects. Table 4. presents the stakeholders have already formed a procurement system for the construction projects and indicates that Designer Group is the lowest $(22,3 \%)$ user of traditional procurement systems. However, Designers are the highest user of Design and Build procurement system. Table 4. also indicate that the highest user of Construction Management procurement systems Sub-contractor respectively. 


\section{IRSETCONF}

Table 4. The stakeholders in the different procurement systems for the construction projects

\begin{tabular}{|c|c|c|c|c|c|c|}
\hline & Client & Consultant & $\begin{array}{l}\text { Designer } \\
\text { Group }\end{array}$ & Sub-contract & Other & $\begin{array}{l}\text { No idea } \\
\text { Don't know } \\
\text { No answer }\end{array}$ \\
\hline Traditional & $40,8 \%$ & $31,4 \%$ & $22,3 \%$ & $44,1 \%$ & $61,5 \%$ & $57,1 \%$ \\
\hline Project Management & $13,5 \%$ & $15,1 \%$ & $18,4 \%$ & $9,9 \%$ & $15,4 \%$ & $14,3 \%$ \\
\hline Management Contracting & $4,1 \%$ & $7,0 \%$ & $8,7 \%$ & $4,3 \%$ & ,0\% & ,0\% \\
\hline Design and Build & $29,7 \%$ & $33,7 \%$ & $38,8 \%$ & $24,8 \%$ & $7,7 \%$ & $14,3 \%$ \\
\hline BOOT, BOT, BOO & $1,8 \%$ & $1,2 \%$ & $1,9 \%$ & $1,2 \%$ & ,0\% & $7,1 \%$ \\
\hline Construction Management & $6,3 \%$ & $9,3 \%$ & $5,8 \%$ & $13,0 \%$ & ,0\% & ,0\% \\
\hline Partnering & ,9\% & ,0\% & $1,0 \%$ & $1,2 \%$ & $7,7 \%$ & ,0\% \\
\hline Other & ,9\% & ,0\% & ,0\% & ,0\% & $7,7 \%$ & ,0\% \\
\hline $\begin{array}{l}\text { No idea } \\
\text { Don't know } \\
\text { No answer }\end{array}$ & $2,1 \%$ & $2,3 \%$ & $2,9 \%$ & $1,2 \%$ & ,0\% & $7,1 \%$ \\
\hline
\end{tabular}

\section{Conclusion}

Construction procurement system is the organizational framework adopted by the client for the management of design and construction of a project. The evaluation of procurement systems and to choose the most suitable system is a complex decision problem. Different procurement systems are used for different projects and the correct choice may help to avoid problems and be the key to the attainment of project-specific goals. The system features causing different results in project quality, budget and timing of the procurement system. Project performance is determined along the parameters of procurement systems have their own advantages and disadvantages meaning that there is no procurement system that can guarantee all of the parameters identified by project stakeholders. Therefore, the selection of a procurement system should be based on the parameters that bear more significance to the project owner or client. For example, if a client considers adherence to cost and time as the indicators of project performance then the turnkey procurement system will be the best option but if the client considers project quality as the main indicator then the design-build and the traditional systems will be the best procurement systems for the client. These results prove that the control and coordination of the sector dynamics are achieved through the contractors. As a result, the most important percentage $(78,8 \%)$ of the construction projects was carried out for the private sector. 


\section{IRSETCONF}

This is also another proof that the dynamics of the sector is deeply rooted in construction companies. In other words, customers in completed projects are in the private sector. Therefore, the economic advantage of the contractor companies with the high rate private projects creates beneficial authority for them within the Turkish construction industry. Therefore, the study recommends that public sector customers, such as government and municipal councils, be advised of the benefits of using other innovative and collaborative methods like Construction Management and Partnering for procurement of construction projects, as they will lead to the achievement of most of the project objectives.

\section{References}

[1] Adenuga, O.A. (2013). Comparison of the performance of traditional and direct labour methods of project procurement: A case study of some selected projects of the Nigerian Army. Ethiopian Journal of Environmental Studies and Management, 6(1):21-30.

[2] Akiner, I., \& Akiner, M. E. (2009). Evaluation of Turkish construction industry through the challenges and globalization. Organization, technology \& management in construction: an international journal, 1(2), 64-71.

[3] Alhazmi, T. and McCaffer, R. (2000). Project Procurement System Selection Model. Journal of Construction Engineering and Management, 126(3), 176-184.

[4] Arditi, D. and Ongkasuwan, D. (2009). Duties and Responsibilities of Construction Managers: Perceptions of Parties Involved in Construction. Journal of Construction Engineering and Management, 135(12), 1370-1374.

[5] Boeckmann, A. (2009). A Global Challenge for the Engineering/ Construction Industry. Leadership and Management in Engineering. Vol. 9. No.3 pp. 103-104.

[6] Chan, D.W.M. \& Kumaraswamy, M.M. (1997). A comparative study of causes of time overruns in Hong Kong construction projects. International Journal of Project Management, 15(1):5563.

[7] Chang, C. (2009). How Far a Contract Can Be Stretched? The First Building Block for Procurement Engineering. Construction Research Congress. 288-297.

[8] Crumm, J. (2012). Procurement and Construction Management. Managing Gigaprojects: $197-$ 217. Retrieved from: http://dx.doi.org/10.1061/9780784412381.ch10. Accessed on [20.07.2017].

[9] Davidson, C.H. (ed.) (1998) Procurement - the way forward: proceedings of CIB W92 Symposium, Universite de Montreal, Montreal, CIB publication 203. (cited from McDermott, 1999) 


\section{IRSETCONF}

[10] Doloi, H. (2013). "Empirical Analysis of Traditional Contracting and Relationship Agreements for Procuring Partners in Construction Projects." Journal of Construction Engineering and Management, 29(3), 224-235.

[11] Elzarka, H. (2009). Best Practices for Procuring Commissioning Services. Journal of Management in Engineering, 25(3), 155-164.

[12] Fisk, E. R., \& Reynolds, W. D. (2013). Construction Project Administration. Pearson; 10 edition, 2013, ISBN-13: 978-0132866736

[13] Grau, D., Back, W., and Prince, J. (2012). "Benefits of On-Site Design to Project Performance Measures." Journal of Construction Engineering and Management, 28(3), 232-242.

[14] Gruneberg, S., \& Hughes, W. (2004). Analysing the types of procurement used in the UK: a comparison of two data sets. Journal of Financial Management of Property and Construction, 9(2), 65-74.

[15] Haponava, T. and Al-jibouri, S. (2012). "Proposed System for Measuring Project Performance Using Process-Based Key Performance Indicators." Journal of Management in Engineering. Vol. 28 (2), 140-149.

[16] Kumaraswamy, M. M. (1994). Growth strategies for less developed construction industries. In Tenth Annual ARCOM Conference: Advances in Construction Management Research.

[17] Latham, M (1994), Constructing the Team, HMSO, London

[18] Leu, S. and Lin, Y. (2008). "Project Performance Evaluation Based on Statistical Process Control Techniques. Journal of Construction Engineering and Management. Vol. 134 (10), 813-819.

[19] Lopez, R. and Love, P. (2012). Design Error Costs in Construction Projects. Journal of Construction Engineering and Management, 138(5), 585-593.

[20] Love, P.E.D., Skitmore, M. and Earl, G. (1998). Selecting a suitable procurement method for a building project. Construction Management \& Economics, Vol. 16 No. 2, pp. 221-233.

[21] Martins, R. and Taylor, R. (1996). Cultural identities and procurement, in R. Taylor (ed.) North meets south: proceedings of CIB W92 Procurement Systems Symposium, University of Natal, Durban, (cited from McDermott, 1999)

[22] Masterman, J.W.E. (2002), An Introduction to Building Procurement System, 2nd ed., Spon Press, London.

[23] McDermott, P. (1999). Strategic and emergent issues in construction procurement, in Rowlinson, S., McDermott, P. (Eds), Procurement Systems: A Guide to Best Practice in Construction, E\&FN Spon, London 


\section{IRSETCONF}

[24] Migliaccio, G. C., \& Shrestha, P. P. (2009). Analysis of design-build procurement activities durations for highway projects. In Construction Research Congress 2009: Building a Sustainable Future (pp. 229-238).

[25] Muriro, A., \& Wood, G. D. (2010). A comparative analysis of procurement methods used on competitively tendered office projects in the UK.

[26] Mustapha, F.H., Naoum, S.G. and Aygun, T. (1994) Public sector procurement methods used in the construction industry in Turkey, in S.M. Rowlinson (ed) proceedings of CIB W92 Procurement Systems Symposium, University of Hong Kong, Hong Kong, CIB publication 175, 229-234. (cited from McDermott, 1999)

[27] Newcombe, R. (1994) Procurement paths - a power paradigm, in Proceedings of CIB W92 Symposium: East Meets West: Procurement Systems, Rowlinson, S.M. (ed.), CIB Publication No. 175, Department of Surveying, University of Hong Kong.

[28] Oshungade, O. O., \& Kruger, D. (2015). A Comparative Study on the Procurement Methods used in the Construction Industry of South Africa. In 3rd IPMA Research Conference, Stelleboch, 25-26 November 2015.

[29] Oyegoke, A. and Kiiras, J. (2009). Development and Application of the Specialist Task Organization Procurement Approach. Journal of Management in Engineering, 25(3), 131-142.

[30] Ozdoganm, I. D., \& Talat Birgonul, M. (2000). A decision support framework for project sponsors in the planning stage of build-operate-transfer (BOT) projects. Construction Management \& Economics, 18(3), 343-353.

[31] Plugge, P. W. (2007). An evidence-based comparison of construction project delivery. PhD Dissertation, Colorado State University, Fort Collins, Colorado.

[32] Rahmani, F., Maqsood, T., \& Khalfan, M. (2017). An overview of construction procurement methods in Australia. Engineering, Construction and Architectural Management, 24(4), 593609.

[33] Riley, W., Lewis, T.M. (2008). The Politics of Procurement, building abroad - procurement of construction and reconstruction projects in the international context, a conference-workshop organized by the IF Research Group, Montreal, Canada. October 23-25, 2008.

[34] Rowlinson, S. (1999). Selection criteria, in Rowlinson, S. and McDermott, P. (Eds), Procurement Systems: A Guide to Best Practice in Construction, E\&FN Spon, London, pp.276299.

[35] Shrestha, P.P., O'Connor, J.T. \& Gibson, G.E. (2012). Performance comparison of large Design-Build and Design-Bid-Build highway projects. Journal of Construction Engineering and Management, 138(1): 1-13. 


\section{İRSETCONF}

[36] Shrestha, P. and Mani, N. (2013). "Impact of Design Cost on Project Performance of DesignBid-Build Road Projects." Journal of Management in Engineering 10.1061/(ASCE)ME.19435479.0000220.

[37] Sobin, N., Molenaar, K., and Gransberg, D. (2010). " A Synthesis of Procurement Approaches for High-Performance Buildings. Construction Research Congress. 1366-1375.

[38] Tiong, R. L. (1990). BOT projects: Risks and securities. Construction Management and Economics, 8(3), 315-328. 